\title{
The ASIL as an Epistemic Community
}

Charlotte Ku

Texas A\&M University School of Law, cku@law.tamu.edu

Follow this and additional works at: https://scholarship.law.tamu.edu/facscholar

Part of the Law Commons

\section{Recommended Citation}

Charlotte Ku, The ASIL as an Epistemic Community, 90 Am. Soc'y Int'I L. Proc. 584 (1996).

Available at: https://scholarship.law.tamu.edu/facscholar/472

This Article is brought to you for free and open access by Texas A\&M Law Scholarship. It has been accepted for inclusion in Faculty Scholarship by an authorized administrator of Texas A\&M Law Scholarship. For more information, please contact aretteen@law.tamu.edu. 
Three comments, on the program of this Annual Meeting. We have answered the theme question in various ways, and we have done some things less well, others better. The focus of a political scientist differs from that of an international lawyer, dealing more with process than with outcome. We have taken a relatively simplistic look at outcomes-that is, we have often looked at whether international institutions have done what they said they were going to do; we have not looked nearly so much at whether they fixed the problems they were trying to fix. The second point that emerges very clearly is that there is indeed a multiplicity of institutions, which causes various problems for nongovernmental as well as for governmental institutions. There is multiplicity without a clear hierarchy; therefore, coordination problems arise. We did not address these coordination problems very well, nor did we address the fact that many states are terribly overburdened by the multiplicity of institutions. The average number of memberships in international institutions for a state is now sixty. Very few countries are capable of managing memberships in sixty organizations. That weakens the policy-making mechanisms of international institutions, and we have not thought through how that may be corrected. Thirdly, we addressed in some ways the issue of institutional change-most clearly in our discussions of the crisis between the United States and the United Nations. In one way, it is a crisis about legal obligations. It is also, though, a crisis about how institutions change-and how we make decisions about how they change. It should not surprise us, looking at domestic institutions, that the process is quite messy. We did not address particularly how that process might be improved and strengthened. That is the key issue we must face as we think about making international institutions more effective and more accountable.

\section{The ASIL as an Epistemic Community}

\section{By Charlotte $\mathrm{Ku}^{*}$}

My inclusion on this panel as Executive Director of a private membership organization may in itself demonstrate the change that has taken place in international affairs to allow such an organization to be considered an international institution. The Society is international in its composition, its reputation, and-more formally-its designation as an organization in consultative status with the UN Economic and Social Council (ECOSOC). Yet ten years ago, the Society would not have been represented on this panel as an international institution.

To provide a focus for this wrap-up comment, I have adopted the conceptual framework outlined by Peter Haas in the Winter 1992 issue of International Organization, entitled "Epistemic Communities and International Policy Coordination." Borrowing the term from natural science, Haas defines an epistemic community as "a network of professionals with recognized expertise and competence in a particular domain and an authoritative claim to policy-relevant knowledge within that domain or issue area." outline how these knowledge-based communities shape policy by "articulating the causeand-effect relationships of complex problems, helping states identify their interests, framing the issues for collective debate, proposing specific policies, and identifying salient points for negotiation."2 This not only serves as a description of international law, but also more specifically describes the American Society of International Law. We may,

* ASIL Executive Director.

'See Peter Haas, Introduction: Epistemic Communities and International Policy Coordination, 46 INT'L OrG. 3 (Winter 1992).

${ }^{2} I d$. at 2 . 